\title{
Marketing Innovation Through Integrated Social Media in Small Bussiness Wood Artists by Karya Langit Mangunan Bantul
}

\author{
Indro Herry Mulyanto ${ }^{1}$, Agung Prabowo ${ }^{2}$ \\ ${ }^{1}$ Bussiness Administration, Pembangunan Nasional Veteran University, Indonesia \\ ${ }^{2}$ Communications, Pembangunan Nasional Veteran University, Indonesia
}

\begin{abstract}
This study aims to design a way of marketing wooden handicraft products in the 'Karya Langit' Craftsmen Group. Product marketing originally relied on word of mouth (WOM). In this research, marketing is done using integrated social media. Marketing through integrated social media is assumed to expand the market and allow craftsmen to communicate with consumers without the constraints of distance or pandemic situations. The method used by the researcher is a qualitative method that is exploratory in nature. Exploration here is in the context of extracting material to create social media content, both images, and product creation processes. The steps taken are (1) Exploring material that will be used as content on social media; (2) Processing the material to be used as content on social media; (3) Creating promotional applications on social media; (4) Training on content creation and uploading to social media. The results showed that 'Karya Langit' woodcraft products have strength in the types of kitchen utensils and health accessories. As for the type of decoration they bring from outside. It still takes time to educate the craftsmen to promote on social media because the process, according to them, is not instant.
\end{abstract}

Keywords: Integrated social media marketing, Small Bussiness, Kaki Langit

This is an open access article under the CC-BY-NC license

\section{INTRODUCTION}

Since the Covid-19 emergency was declared in March 2019, life in all sectors has undergone very significant changes. The impact on the economic sector is a matter of concern. The wheels of the economy were disrupted due to the limited mobilization of citizens. The tourism sector is one of the most affected sectors. The risk of transmitting the virus makes the desire of citizens to travel less. The excitement of traveling that has been felt since the widespread use of social media has completely stopped. Tourism which was originally based on Instagramable tourism, was forced to stop by Covid-19. In fact, through the Generation Pesona Indonesia (GENPI) program, the Ministry of Tourism is trying to elevate Instagramable tourism (digital tourism) to become leading tourism for citizens.

One of the seven digital tours built by the government is the Pasar Setu Minggu (Semi) Kaki Langit. Pasar Semi Kaki Langit is a culinary tour that sells a variety of traditional Yogyakarta food/snacks. This tour was established to complement the tourist destinations of the Mangunan area, which are dominated by natural tourism. Since its establishment, this tour managed by the local community has been visited by many tourists. Seeing its development, the manager of the Pasar Semi Kaki Langit feels that this tourist destination can be used as a source of income for residents. Until the end of 2019, this tourist destination continued to be developed and became one of the favorite destinations in the Mangunan Region. The economic impact is quite positive. The wheels of the local people's economy are moved through the provision of food, travel services to the emergence of guest houses in each of the residents' homes. 
The development of the Mangunan Imogiri Tourism Village in Bantul is a means to accommodate people who love their village. They work together to carry out their respective activities with tourism as a binding knot by prioritizing the value of local wisdom so that the community becomes more prosperous. This Kaki Langit tourism was developed with the concept of community-based tourism (CBT).

The management of the Kakilangit Mangunan Tourism Village is the Mangunan Hamlet Community. The community forms a Tourism Village Manager in which there are many community elements that play a role. In 2016 the Mangunan tourism village won the best award for the three categories of CBT-based tourism villages at the provincial level.

Mangunan tourism village has a lot of potentials, such as wood crafts. This potential can be developed into a superior craft center. The results of wooden craft centers such as pyramid roofs, key chains, candle holders can be developed into models and then marketed more widely through internet media. Marketing widely requires appropriate marketing promotion media. Therefore, it requires information technology in the form of the web and other social media.

However, since Covid-19 hit, tourist visits have stopped altogether. The wheels of the economy are disrupted due to the absence of sources of income. Tourism managers have made various efforts to restore conditions as before. Construction of Covid-19 protocol facilities such as handwashing stations, provision of masks, temperature detection devices, landscape design of tourist attractions in accordance with the provisions of the Covid-19 protocol, and several others. The latest effort is the certification of the Covid-19 protocol from the government. The result is Pasar Semi Kaki Langit is certified A. However, all these efforts have not been able to move tourists to visit.

In the midst of the economic downturn, several residents took the initiative to explore other economic potentials. So the 'Works of Heaven' Wood Crafts Group was formed. This group is targeting the opportunity for the abundance of natural wood resources in residential areas without destroying the woody plant ecosystem. Karya Langit produces a variety of wood lathe crafts, including bowls, bracelets, prayer beads, kitchen utensils, and so on. The proceeds from the sale of this craft have more or less the potential to become an alternative income for residents to replace the spring market tourist attraction.

Figure 1. Growth of MSME Actors Transacting at Tokopedia 2020

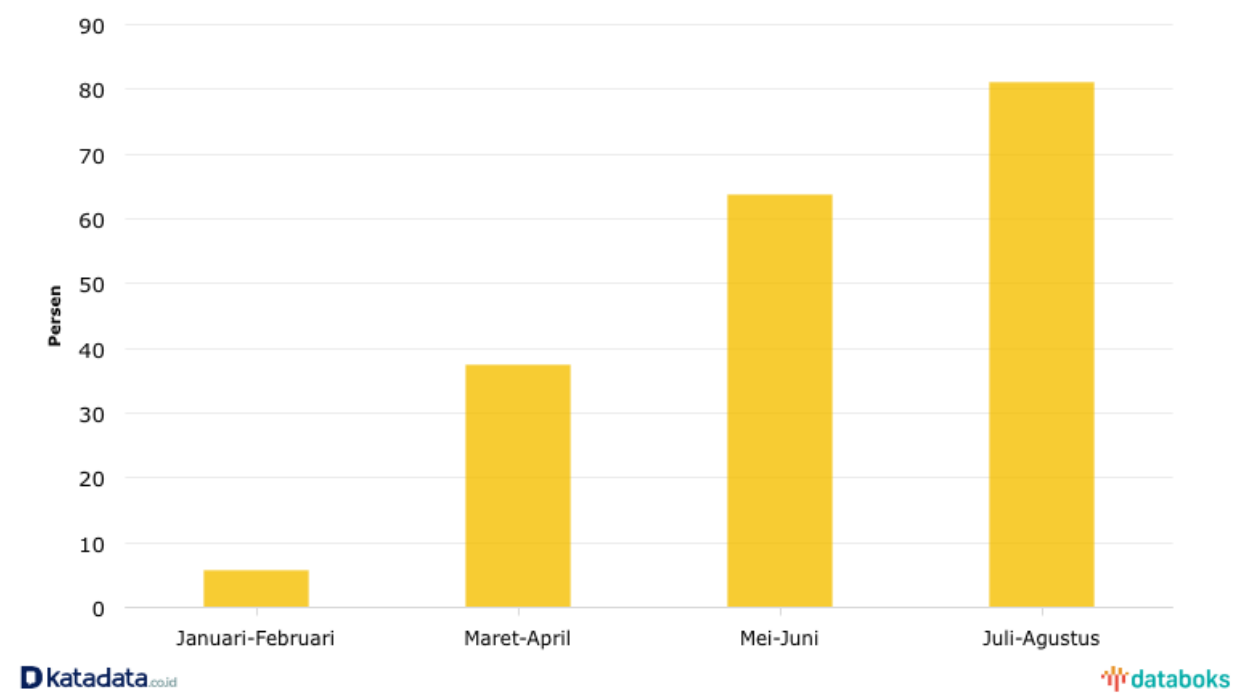

Source: LPEM-FEUI 
Product marketing currently relies on orders from other parties. Active marketing has not been done. Craftsmen were just waiting for orders. If not, then the production activity stops. This fact raises the problem in this research. Potentially, the people of Kaki Langit have the opportunity to develop this craft as a main source of income. Another advantage, this craft can support tourist activities as a souvenir. This means that if this woodcraft is developed, the market potential is large and supports each other with tourism activities. This article is elaborated on how to eradicate poverty through expanding the market for lathe wood crafts for the residents of the Mangunan hamlet based on social media and mobile phone technology.

\section{LITERATURE REVIEW}

\section{Social Media as A Marketing Tool}

Technological developments have a major impact on organizations. The emergence of online technology has revolutionized marketing operations worldwide (Baird \& Parasnis, 2011). Now there is high competition in the market and customers have the opportunity to make better decisions for the various goods and services available. In this competitive situation, organizations need to be vigilant to maintain customer loyalty. Reducing the communication gap between companies and consumers can be a good way to create good relationships, which can further help develop a better understanding of consumer needs and wants. Social media plays an important role in this, and companies are benefiting from a social media-friendly approach to building their relationships (Hachinski et al., 2010). Social media sites are communication links used to bind people together. Research has proven that people are moving towards using social media to gain access to information, ideas, and opportunities (Golder and Donath, 2004).

Social Media Networks are applications that allow users to build private websites that are accessible to other users for content exchange and personal communication (Bowden, 2009). Social media, according to Bowden and Lewis, can be characterized as applications, platforms, and online media that aim to facilitate interaction, collaboration, and content sharing.

According to research studies Forrester, David M., and Cooperstein, Dernoga M (2011), J, Companies (brands) are gradually changing their advertising priorities to better align with current buyers. Shoppers today are tech geeks and social media maniacs. Therefore, the development of social media network services in brand management and marketing has brought us to pay attention to these networks.

Evans argues that although communication is a core dimension of Social Media networks, not all platform categories are suitable for all marketing purposes, as most platforms are not suitable for information, collaboration, and even for building relationships.

The purpose of social networks is primarily for communication and exchange of ideas of mutual interest among peer groups or communities through frequent communication initiated by marketers in interactive social networks (Gummesson, 2011). Cheung et al. (2011) explore customer engagement in online social platforms. The conceptual model developed shows that customer engagement in online social media platforms is a construction consisting of strength (level of energy and mental resilience), absorption (level of concentration and preoccupation), and dedication (sense of significance, enthusiasm, inspiration, pride, and challenge) towards the online social platform, driven by social engagement and interaction.

According to Kozinets et al. (2010), as brands continue to infiltrate relationships in social networks, the market's "self-interest logic" can undermine the communal ideals of "sharing/care" and threaten the group's traditional social contract. Interaction with these brands in terms of adding content, leaving 
comments, and spreading messages create tension for the individuals involved and makes them less likely to share content with their strong ties.

According to (Warc, 2012a) the online context of Social Media has become of great interest to marketing practitioners as new Social Media platforms are rapidly emerging as valuable tools at the center of their customer engagement efforts.

While Social Media marketing (or Social Media Optimization) is being focused on by every business in the world today, it is important to consider various effective Social Media marketing strategies as described below: Companies are currently providing lucrative offers to their customers as free coupons, discounts on direct cash payments and gift offer to promote their business, drive in-store foot traffic, and also provide incentives to keep checking back. Keep coupons up to date, and try to change them every month to keep them relevant and keep customers interested. Business is part of the community; It is a better idea to use social networking sites by creating web pages to interact with customers. Giving thanks online to all the brands that help make a business shine is easy and rewarding. We all know that a company can't sell 24/7, especially when it's trying to build meaningful relationships with its customers and fans. It should try to inform customers about the nature of the business, and Social Media can play an important role by sharing photos or jokes with prospects.

Regardless of the type of post being shared, make sure it's relevant to their area of interest. It engages customers because Customers are the greatest ambassadors, so keeping their attention is very important, and content is key! Share solid information with them, and they will keep coming back for more.

\section{The Power of Social Media as a Product Mass-Personal Communication Channel}

Mass-personal communication is a new concept created by the emergence of social media. This concept challenges previous opinions that see mass communication and interpersonal communication as separate concepts (Berger and Chaffee, 1988; Hawkins et al., 1988; Wiemann et al., 1988).

The basic concept of Masspersonal Communication is driven by (a) Individuals using conventional mass communication channels for their interpersonal communication needs; (b) Individuals use interpersonal communication channels for mass communication, and (c) Individuals engage in mass communication and interpersonal communication simultaneously. This concept emphasizes the selection and use of communication channels by communicators in pursuing their relationship goals. The focus is not on channel characteristics (O'Sullivan, 2000), affordability of infrastructure (Castells, 2010), or on specific channels or on a mix of the user, technical, and interactive attributes (Eveland, 2003). In relation to marketing needs, this personal and mass character has the power to penetrate personal products and massive product publications in one activity.

The concept of mass personal communication examines the assumption that the channel used will determine the type of communication (. Existing mass communication science assumes (a) communication requires the use of traditional mass communication channels (e.g., television, radio, newspapers) and (b) messages through mass communication channels are (by definition) mass communication (Kuhn, 1996).

Mass personal communication recognizes that individuals can use traditional mass communication channels for interpersonal communication. Interpersonal communication experts assume (a) interpersonal communication occurs through traditional interpersonal channels and (b) messages through interpersonal communication channels are inherently interpersonal communication. Personal mass communication also recognizes that individuals can use traditional interpersonal channels for mass communication. Most importantly, the concept of mass personal comprehensively includes an increasing 
array of forms and practices of CMC that are in no way compatible with conventional conceptualizations of either mass or interpersonal communication while still taking into account older forms of communication.

The difference between interpersonal communication, mass communication, and mass-personal communication is (a) exclusivity of message access and (b) message personalization. This dimension is a distillation of the characteristics that distinguish conventional conceptualizations of mass communication, and interpersonal communication that persists after trimming the elements of each definition that exhibit limitations when applied to various communication activities made possible by newer communication technologies (e.g., mediated vs. unmediated; one-way vs two-way; one-to-one vs one-to-many; recipient's personal knowledge vs unknown others). These dimensions provide a new approach to mass and interpersonal communication that demonstrates the relationship between them while establishing a framework for defining forms of communication that do not conform to traditional mass or interpersonal communication but are increasingly common.

\section{Web Communication Model}

The web communication model describes the communication process that occurs between customers and customers (C2C) or customers and opinion leaders. Communication between C2C can be negative if a customer who has had a bad experience with a product will tell other potential customers about a bad product experience, but $\mathrm{C} 2 \mathrm{C}$ can also be useful if customers who have had good experiences with a product and tell other customers or potential customers (Bungin, 2017;52).

$\mathrm{C} 2 \mathrm{C}$ is $\mathrm{P} 2 \mathrm{P}$ or people to people. This means that $\mathrm{C} 2 \mathrm{C}$ is direct communication between one person to another. But it can also be between the sender (communicant) to people. Communicants are people who disseminate information to others in the web network, and that information will spread everywhere in the network. Web management of information becomes out of control because the information will be stored in global data storage programs such as I-cloud, Dropbox, Mailbox, Google, and so on, so it is estimated that information on the web network will be "eternal" in this system (Bungin, 2017; 53)

The character of the web communication model is; (1) disseminate information in the network very quickly, (2) information is difficult to control communicants, (3) information is stored "eternally" in the network, (4) information is open to many people, (5) generic information can disappears by itself if it is attacked by a virus, (6) for certain purposes information can be locked, and not everyone can access it. Interactivity in the context of new media shows the ability for users (media) to engage directly and change the images or text they access. This means that interactivity in new media will provide opportunities for media consumers to take more active participants in the world of mediated communication. In this case, the new media user is not only a viewer but also a user.

The characteristics of new media have an influence on the communication process between humans, especially with regard to the way and culture of the society in using and understanding communication technology. The interaction characteristics of the internet make it possible for the communication process that occurs not to be one-way like what happens in traditional media, but to become more interactive through new media (Ida, 2015: 192).

The process of adapting the use of media as a means of promotion is a set of "open system" assumptions about human nature as an adaptive living entity, as follows (Ida, 2015: 192)

a. Assumption 1: Humans have an inherent drive to adapt and develop

b. Assumption 2: Adaptation to one's social environment takes place through communication

c. Assumption 3: Adaptation is a complex and dynamic process 


\section{RESEARCH METHOD}

The parties involved in this digital marketing development activity are the 'Karya Langit' Wood Crafts Group as Partners and the Yogyakarta Veterans UPN research team. The first step is to identify needs

a. Making woodcraft catalog

b. Connection of the woodcraft product catalog with the Kaki Langit Website

c. Develop a Business Account containing a catalog of wood craft products on Instagram and business WhatsApp.

d. Connecting websites, catalogs with marketplace

e. Creating an independent e-commerce management structure

f. Training on the use and management of websites, digital catalogs, business accounts on social media, and stalls in the marketplace

g. Assistance for three months.

The following stages of the working procedure:

\section{Stage 1. Creating an Independent E-commerce Management Structure}

Creating an independent e-commerce management structure and understanding the covid protocol. The management structure is local human resources prepared by partners to manage social media content and monitor sales in the marketplace. The management structure consists of the chairman, promotion section, marketing section, content management section, and finance section.

\section{Stage 2. Technology Development to be Transferred to Partners}

a. Develop an online catalog. The website does not yet contain complete woodcraft products. Whereas in the sales business, the catalog must be complete with product info, prices, languages, appearance, and other supporting info. Then the catalog needs to be developed.

b. Connecting the online catalog with the website. In order to be integrated, the online catalog needs to be integrated with the website. Website visitors can view the catalog from the web.

c. Develop a Business Account containing a catalog of woodcraft products on Instagram and WhatsApp. A catalog of Instagram and WhatsApp versions should also be created. Visitors generally do not come right away, but first, look around the company's products and situation using a cell phone. Then the catalog is also prepared for visitors on social media Partners are involved in each of the above activities so that partners are ready to accept technology transfer after the product is finished and ready to use.

\section{Stage 3. Connecting the website, catalog with the marketplace}

Website and catalog visitors can make transactions with partners using the marketplace because the marketplace is connected to the website. Likewise, visitors to the marketplace can view the web and partner catalogs because the marketplace is already connected to the web and partner catalogs. This will certainly increase the trust of visitors to transact with partners using marketplace services, especially since the marketplace has implemented the covid19 protocol for sending goods to consumers. 


\section{Stage 4. Training and Technology Transfer}

a. Content management training on social media, Instagram and Whatsapp. This training contains managing Instagram and catalogs on WhatsApp.

b. Marketing management training in the marketplace. This training contains the management of buying and selling transactions, data updates, and management in the marketplace.

\section{Stage 5. Assistance for three months}

Assistance is carried out to monitor technology transfer after technology products are handed over to partners.

\section{FINDING AND DISCUSSION}

As an area surrounded by forest, Kaki Langit has abundant timber wealth. In the utilization of wood into processed products, a lot of leftovers from processed wood are not utilized. The Covid-19 crisis has stimulated the affected residents of the Kaki Langit to take advantage of the wood waste. Wood waste that was originally abandoned just like that is then processed into several grinding tools by turning. By using a simple production tool (motorcycle engine), the people of Kaki Langit turn the waste. The result turned out to be quite economical value. The problem is, so far, they only accept orders from wholesalers. All wood materials from the order and they only work and get services only.

Considering the abundance of raw materials in the Kaki Langit environment, in this service, grinding tool craftsmen are directed to process existing wood waste and make it one of the typical products of Kaki Langit. By being given the brand 'Kaki Langit', this milling product also raises the name of Kaki Langit.

During the pandemic, the income of the people of the Kaki Langit area, which previously relied on the tourism sector, declined. This wooden craft is actually a substitute, in addition to making traditional herbal medicine. The problem faced is product marketing, although, from the aspect of product quality, it still needs to be improved.

In the midst of the current pandemic, the urgent problem to overcome is marketing, considering that income generation is related to their survival. Meanwhile, product quality problems can be solved later.

Marketing of the product 'Karya Langit' so far still relies on the arrival of orders. Some craftsmen have used social media, but it has not been optimally worked on. The problem with managing social media lies in the limited content uploaded. A series of interrelated problems leads to limited product variants, so content exploration is also limited.

After observing, there are several unique products produced by 'Karya Langit' craftsmen, one of which is a wooden bracelet. According to the craftsmen, this wooden bracelet is made of certain wood, which is believed to have 'magical' powers to nourish the wearer. According to him, many ordered even though the price was quite high. This wooden bracelet consisting of a series of wood grains resembling prayer beads is marketed for 500 thousand rupiahs. The price is quite high for a small product made of wood. However, craftsmen are able to convince consumers about the value contained in these products.

The marketing of this health bracelet product is also waiting for orders. Sales rely on words of mouth (WOM). Although the craftsmen claim to have a place in the marketplace, not many consumers have ordered from the marketplace.

After observing, it turns out that the marketplace is not managed properly. Likewise, his Instagram account. The view of the Instagram account is not active, and there are only four photos in it. 
RSF Conference Series: Business, Management and Social Sciences, Vol. 1 (3), 226-235

Marketing Innovation Through Integrated Social Media in Small Bussiness Wood Artists by Karya Langit

Mangunan Bantul

Indro Herry Mulyanto, Agung Prabowo

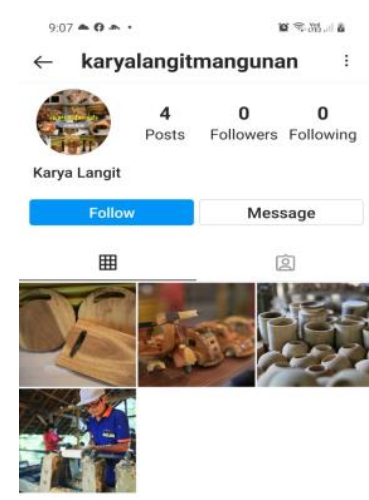

กุ $Q$ ๑

Figure 1. Unmanaged Karya Langit Instagram Account

From the findings in the field, then the development of social media was carried out by integrating it into one social media and connecting with other social media. Researchers, in this case, developed Whatsapp (WA) Bisnis as the beginning of a marketing medium and at the same time transacting. WA Business was chosen because this application is very familiar and popular in the community. The WA Business design is made in such a way that it makes it easier for craftsmen and users. Some of the WA Bisnis displays are as follows:
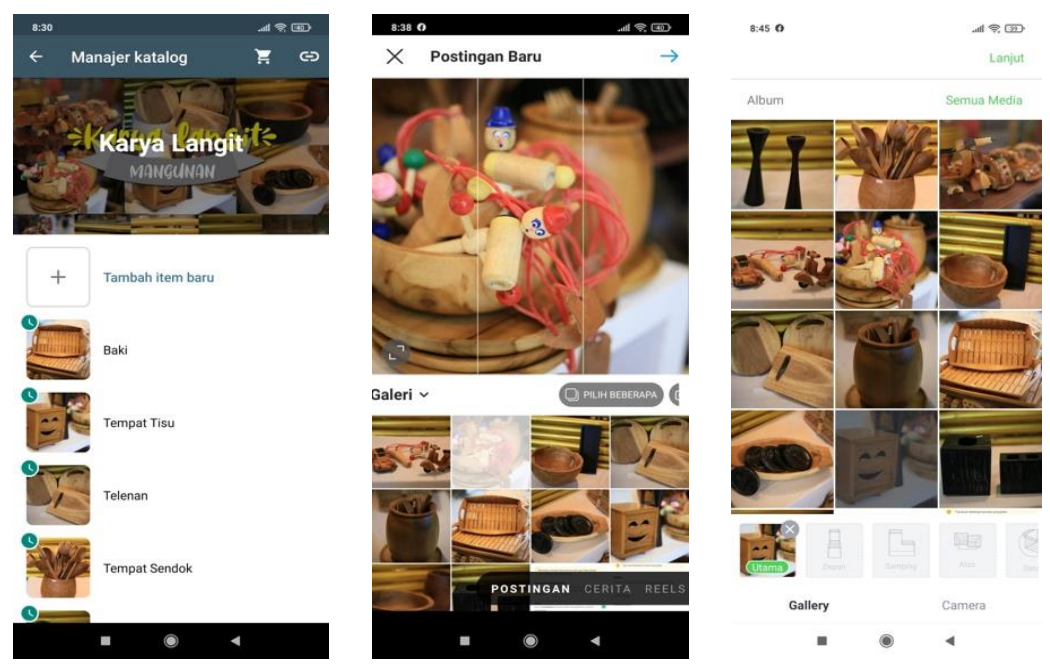

Figure 2. Karya Langit Business Whatsapp Display

Currently, the impact of marketing through WA Bisnis has been felt. Some customers have made transactions through this application, although not significantly. Many variables affect the lack of consumer response in the midst of this Covid-19 pandemic. Although it has not shown a significant impact, 
it is believed that the marketing potential through integrated social media will be able to help increase the sales of Karya Langit's wood products.

\section{Discussion}

The Mangunan community actually has extraordinary resilience in the face of economic blows due to the Covid-19 pandemic. They make various efforts, including the use of wood waste. From his spirit, no doubt. However, creativity still needs to be improved.

This research only touches on the marketing aspect. Marketing is considered more important than the development of creativity. However, these are two things that are interconnected. However, increasing creativity requires a relatively long time. Even though maintaining the continuity of income is a priority in the midst of this Covid-19 pandemic.

Judging from its potential, the available resources in the Kaki LAngit Tourism Object area can be further developed as a major tourism supporter. As a tourist attraction for traditional culinary markets, Pasar Kaki Langit already has a fairly large market. To add to the tourist attraction, this processed wood product can be used as a souvenir. However, to arrive at this idea, the quality of the craftsmen's resources still needs to be improved.

\section{CONCLUSION}

The Kaki Langit Art Market is a tourist attraction that has collapsed due to the Covid-19 pandemic. As an object that was previously the main source of income, the surrounding community must look for other sources that ensure their survival. One of the businesses developed is the 'Karya Langit' wood craft. This craft utilizes wood waste in the surrounding environment.

From the potential of its products, the wooden craft of Langit is able to fill the market needs, including kitchen utensils. However, there are other souvenir products. The main obstacle among craftsmen is product marketing. Products have been relying on demand from consumers. If there is no demand, then there is no production.

These obstacles have been attempted through the creation of social media accounts and marketplaces. However, due to inadequate content provision capabilities, the appearance of these social media accounts has stopped. This study tries to provide a new alternative, product marketing using integrated social media. Whatsapp Business Social Media as the main media. The result is quite interesting for craftsmen. In addition to appearing excitement, the impact of this marketing media is quite felt, although not yet significant. The trial stage has not yet had a significant impact, perhaps because of the pandemic factor that has not been able to restore the community's economic capacity.

\section{REFERENCES}

Baird, Carolyn Heller dan Gautam Parasnis, 2011. From Social Media to Social Customer Relationship Management. September 2011. Strategy and Leadership 39(5):30-37

Berger CR and Chaffee SH (1988) On bridging the communication gap. Human Communication Research 15: 311-318.

Bowden, J. L.-H. (2009). The Process of Customer Engagement: a Conceptual Framework. [Article]. Journal of Marketing Theory \& Practice, 17(1), 63-74. doi: 10.2753/mtp1069-6679170105

Bungin, Burhan. 2017. Komunikasi Pariwisata Tourism Communication. Jakarta :

PT. Fajar Interpratama Mandiri. 
Castells M (2010) The Rise of the Network Society: The Information Age: Economy, Society, and Culture. West Sussex: John Wiley \& Sons.

Cheung et al. (2011). Online social networks: Why do students use facebook?. Computers in Human Behavior. Volume 27, Issue 4, July 2011

Eveland WP (2003) A "Mix of attributes" approach to the study of media effects and new communication technologies. Journal of Communication 53: 395-410.

Golder, S. A., \& Donath, J. (2004). Social Roles in Electronic Communities. In Proceedings of the International Conference of Internet Research (pp. 13-22). Brighton, England.

Gummesson, Evert. 2011. Total Relationship Marketing (3rd edition). DOI:10.4324/9780080880112

Hawkins RP, Wiemann JM and Pingree S (1988) Advancing Communication Science: Merging Mass and Interpersonal Processes. Newbury Park, CA: SAGE.

Ida Ri"aeni. 2015. Penggunaan New Media dalam Promosi Pariwisata Daerah Situs Cagar Budaya di Indonesia. Jurnal : Universitas Muhammadiyah Cirebon. journal.uii.ac.id/jurnalkomunikasi/article/viewFile/7178/6362

Kuhn T (1996) The Structure of Scientific Revolutions. Chicago, IL: The University of Chicago Press. O'Sullivan PB (2000) What you don't know won't hurt me: impression management functions of communication channels and relationships. Human Communication Research 26: 403-431.

Kozinets, Robert V. et all., 2010. Networked Narratives: Understanding Word-of-Mouth Marketing in Online Communities. Journal of Marketing. https://doi.org/10.1509/jm.74.2.71

Wiemann JM, Pingree S and Hawkins RP (1988) Fragmentation in the field-and the movement toward integration in communication science. Human Communication Research 15: 304-310. 